\title{
ENTREPRENEURSHIP, INNOVATION AND GROWTH IN DIFFERENT TYPES OF
} SMALL ENTERPRISE

\section{EMPREENDEDORISMO, INOVAÇÃO E CRESCIMENTO NOS DIFERENTES TIPOS DE PEQUENA} EMPRESA

Recebido em 01.10.2019 Aprovado em 03.12.2019 Avaliado pelo sistema double blind review

José Luiz Contador DOI: https://doi.org/10.12712/rpca.v13i4.38118

\section{jluiz@.feg.unesp.br}

Programa de Pós-graduação em Administração das Micro e Pequenas Empresas/Cento Universitário Campo Limpo Paulista- Campo Limpo Paulista /São Paulo, Brasil

ORCID: http://orcid.org/0000-0002-7952-774X

\section{José Celso Contador}

celsocontador@terra.com.br

Programa de Pós-graduação em Administração/Universidade Paulista- São Paulo /São Paulo, Brasil

ORCID: http://orcid.org/0000-0003-4695-3379

\section{Patrícia Possani de Oliveira}

patpossani@uol.com.br

Instituto Bertrand Russell Ltda - Jundiaí /São Paulo, Brasil

ORCID: https://orcid.org/0000-0001-8139-5961

\section{Walter Cardoso Sátyro}

satyro.walter@gmail.com

Programa de Pós-graduação em Eng. de Produção- Universidade Nove de Julho, São Paulo /São Paulo, Brasil ORCID: https://orcid.org/0000-0001-8139-5961

\begin{abstract}
A quantitative methodology is presented to analyze the extent to which the degree of the various types of innovation influence the growth of the various types of business in the small enterprise and whether entrepreneurial capacity drives these types of innovation. Four types of business were considered (hightech companies, specialized services, companies with own brand products, and companies with conventional processes) and the four classic types of innovation. The methodology is exploratory and supports empirical study applied to a sample of companies. The results showed that the appropriation of some additional value, like own brand, potentiates the differences in the relationship between entrepreneurship, innovation and revenue growth.
\end{abstract}

Keywords: Organizational Performance. Competitiveness. Entrepreneurship. Innovation. Small Companies.

\section{Resumo}

Apresenta-se uma metodologia quantitativa para analisar em que medida o grau dos diversos tipos de inovação influencia o crescimento dos diversos tipos de negócio na empresa de pequeno porte e ainda se a capacidade empreendedora impulsiona esses tipos de inovação. Foram considerados quatro tipos de negócio (empresas de alta tecnologia, de serviços especializados, empresas com produtos de marca própria, e empresas com processos convencionais) e as quatro modalidades clássicas de inovação. A metodologia é exploratória e ampara estudo empírico aplicado a uma amostra de empresas. Os resultados mostraram que a apropriação de algum valor adicional, como marca própria, potencializa as diferenças na relação entre empreendedorismo, inovação e crescimento de receita.

Palavras-chave: Desempenho Organizacional. Competitividade. Empreendedorismo. Inovação. Micro e Pequena Empresa. 


\section{Introduction}

Innovation and technology are relevant drivers for entrepreneurship and economic growth (Peng, at al., 2018, Zachary and Mishra, 2011). Innovation and entrepreneurship can be understood as unceasing and complementary processes, the fuel of the modern economy (Qian 2017, Schmitz, at al., 2017).

Innovation is an important field of research, impacting society (Dodgson at al, 2016, Lado-Sestayo et al., 2017, Zachary and Mishra, 2011, Stott and Tracey, 2018) and enterprises around the world that are being pressured to adapt to changes in the external environment, to stay competitive (Garcia-Herrera et al., 2018, Tomy and Parded, 2017). Maintaining competitiveness is a matter of concern to top managers and innovation professionals, who are looking for a better way to overcome the challenges they encounter in their daily activities (Alexy et al, 2017), supported on good ideas that can generate and enhance their innovation performance (Christensen at al., 2017, Wright at al., 2018).

Innovation and entrepreneurship are interconnected (Arshi and Burns, 2018). Some authors consider that innovation is at the core of corporate entrepreneurship in mature organizations (Duobiene, 2017), others that entrepreneurship is an antecedent to innovation in large companies (Arshi and Burns, 2018), and others that entrepreneurship is an important factor to increase innovation and performance in SMEs (Ahmed, et al., 2018, Niazi, 2017). Entrepreneurship is the heart of innovation activities and innovation is the main characteristics of entrepreneurship (Tao and Qiuying 2008).

This article presents a proposition of a procedure for quantitative evaluation to study the behaviour of the spiral 'innovation, entrepreneurship and growth' for some types of business which are typical of small and medium enterprises (SMEs) in Brazil. More specifically, it sought to verify to what extent the degree of the different innovation types affects the revenue growth of the company and the extent to which entrepreneurial capacity drives innovation in each of the business types studied.

These types of business are: a) companies using conventional processes (CP - labor-intensive and basic technology manufacturing, such as clothing, footwear, etc.), b) specialized service companies (SS - small offices specialized in consulting and development), c) companies that sell own brand products (OB), and d) companies with high-tech products or processes (TEC - for instance, test equipment for electronic plates, special welding process). The CP type of business (companies using conventional processes) is the standard where the majority of SMEs operate, many of them acting as subcontractors. The three other types of business seek to grant some relevance to the companies.

This classification, besides representing typical businesses of small and medium enterprises, at least in Brazil, allows to check whether the appropriation of some additional value, such as an own brand products, technological expertise or technical knowledge, increases the differences in the relationship between entrepreneurship, innovation and income growth.

Innovation, in turn, was classified by the Oslo Manual (OECD, 2005) and Davila et al (2007), in four types: a) product innovation, b) process innovation, c) marketing innovation, and d) organizational innovation.

The study was developed based on an exploratory research by applying statistical techniques on data extracted from a sample of 48 Brazilian small enterprises, which results showed that: a) concerning revenue growth, there is a significant difference between the types of business, b) innovation affects income growth in various degrees depending on the type of business, and c) entrepreneurial capacity also affects innovation in different degrees, in its several types, and in different types of business.

These results showed that to possess some additional value, like own brand products, technological expertise and technical knowledge, emphasizes the differences in the relationship between entrepreneurship, innovation and revenue growth, giving consistency to the proposed methodology. 
A survey in the Scopus and Web of Science database, at the end of June 2019, in the research fields: title, abstract and keywords, from 2013 to 2019, using the research string: entrepreneurship AND innovation AND growth, presented 1,145 documents at Scopus and 1,143 documents at Web of Science. Another research, including SME in the research string, exhibited 38 documents at Scopus and 48 documents at Web of Science, or $4 \%$ of the previous research, showing the reduced number of studies with SME, what is a gap (see Table 1).

Table 1. Research string.

\begin{tabular}{lcc}
\hline \multicolumn{1}{c}{ Research string } & Scopus & Web of Science \\
\hline entrepreneurship AND innovation AND (growth OR success) & 1,145 & 1,143 \\
entrepreneurship AND innovation AND (growth OR success) AND & 39 & 48 \\
SME & & 48 \\
\hline
\end{tabular}

Source: The authors.

We found that most of the international empirical studies addresses the issue of growth from the macroeconomic standpoint (countries' growth based on the performance of their SMEs), as did and Mendez (2013, 2014).

Some Brazilian studies also follow this trend, like Fontenele (2010). We found some articles that aimed at a better understanding of the relationship between entrepreneurship and organization success, such as Fernandes and Santos (2008), Man at al. (2008), Newbert at al. (2008), and Priyanto and Sandjojo (2005). However, considerable part of the articles deals with large companies. Brito at al. (2009), for example, studied the relationship between innovation and organizational performance in large companies of the Brazilian chemical sector, but they neither divided the companies into their various types of business, nor studied innovation in its several types.

Therefore, it seemed appropriate to develop this study whose methodology is applicable to SMEs, in order to study the relationships among the variables degree of innovation, revenue growth rate and entrepreneurial capacity, but dividing the companies into their various types of business, and innovation in its four classical general categories.

The contributions of this article are the proposition of the procedures for the quantitative evaluation of the entrepreneurial capacity in small enterprises and of its degree of innovation, and the several conclusions about the relationships among these two variables and the enterprise revenue growth. The study of the relationship of these three variables confers uniqueness to the article, since our bibliographic research identified studies relating only two of them.

In addition, it was found that, by separating the companies under such criteria, it is possible to achieve more revealing results than those obtained by Varis and Littunen (2010) who in a similar study found that company growth is not affected by innovation category, contrary to the outcome obtained here.

This article is organized in five sections. In the second, we present the literature review on entrepreneurship and innovation in small and micro companies, which provided the theoretical foundations that support the proposed methodology. The third section presents the procedures for the application of the methodology, in the fourth section is presented the results and the discussion of its application to a sample of 48 small businesses. The last section presents the conclusions of the study.

\section{Theoretical Background}

This section presents a literature review on attributes of the entrepreneur and innovation in order to justify the adoption of the proposed methodology. 


\section{Attributes of the entrepreneur}

Many studies have attempted to identify attributes of entrepreneurial individuals. Weber (2005) claims that religious belief would be a motivating factor for entrepreneurial actions, meaning that the environment in which the individual lives and his values and beliefs affect his choice for venturing.

Feuerschütte at al. (2012) argue that competence is expressed in action, based on knowledge and experiences that store and enhance the capabilities of each individual. Zampier and Takahashi (2011), in turn, consider that entrepreneurial learning is an ongoing process that facilitates the development of knowledge needed to start and manage new ventures.

Regardless of the way in which the entrepreneurial capacity of individuals emerges or evolves, this study required the development of an appropriate procedure to evaluate it. To justify the adopted procedure, here follows the traits of the successful entrepreneur, according to the main classical authors.

McClelland (1961) identified a strong psychological element that distinguished successful entrepreneurs: the motivation for achievements or the drive for improvements. This resulted in the possibility of considering entrepreneurship also as a set of behaviours and practices that can be observed and acquired. The behavioural approach to entrepreneurship suggests that such behaviours and practices can be significantly strengthened in people through education and training.

In his studies, McClelland (1961) identified ten personal skills often found in successful entrepreneurs: search of opportunities and initiative, persistence, risk acceptance, demand for efficiency and quality in actions, commitment to work, goals setting, search of information, monitoring and systematic planning, persuasion, independence and self-confidence.

Schumpeter (1985) saw the entrepreneur as an innovator agent and instability creator, in the sense of generating changes that trigger market unbalance through 'creative destruction'. According to him, the entrepreneur would be responsible to combat the natural entropy of the economic cycles, by promoting a new rise and preventing the decline of wealth generation.

Carland at al. (1992), in order to classify individuals into categories, developed the Carland Entrepreneurship Index, which takes into account four functions that best identify the entrepreneur: 1) personality traits, 2) risk propensity, 3) propensity for innovation, and 4) strategic posture.

Bateman and Snell (1998) observe that entrepreneurs are determined and effective leaders, obsessed with opportunities, creative, motivated, confident, and tolerant to uncertainties and risks. According to Hisrich at al. (2010), the skills that distinguish entrepreneurs can be classified into three categories: technical, administrative and personal, the latter being of behavioural nature and involves the ability to take risks, spirit of innovation and persistence. Drucker (1985) states that the key roles of the entrepreneurs are: innovation, risk-taking and a permanent state of unbalance, of breaking paradigms.

In order to develop a multi-criteria model to support the selection of incubator companies, Oliveira and Fontenele (2009) conducted a vast research on the characteristics of the entrepreneur most commonly cited by 34 authors. They have obtained the list of the following fifteen: 1) Persuasion, 2) Initiative (seize opportunities, new ideas), 3) Independence (decision autonomy), 4) Self-confidence (belief in self, motivation), 5) Persistence (strong will, perseverance), 6) Vision (look at the future of the company), 7) Opportunity (ability to identify and explore), 8) Innovation (search for new ideas), 9) Risk (determination to face), 10) Advantage or competitive differential, 11) Coordination (goals, supervision and control), 12) Communication (knowing how to listen, to spread, to transmit), 13) Connectivity, Articulation and Participation (team integration), 14) Management (strategic planning, marketing, negotiation, decision), 15) Feedback (value the feedback of information). 
Korunka et al. (2010) developed a longitudinal study (observing enterprises over 8 years) to analyse the predictors of small business survival risk. A research tool was developed to measure the relevant characteristics of entrepreneurs, their resources and the environment. The characteristics of the entrepreneur considered were: internal locus of control, need of achievement, risk taking propensity, gender and age of business founder.

More recent studies have evoked characteristics related to personality traits, cognitive aspects and human capital, and although they do not fit the types of characteristics to be evaluated in the present study, they deserve to be highlighted, since they show some convergence with the characteristics treated in previous studies.

Olivari (2016) conducted extensive research on characteristics of the entrepreneurs in works published in the last five years that preceded his publication, having identified the following main traits of personalities: need of achievement, internal locus of control and persistent self-efficacy. Olivari (2016) also identified within the cognitive characteristics: high alertness, creating style, role models (start-up motive) and desire to build successful business. Bianchi at al. (2018) state that small business owners and entrepreneurs should develop their abilities to detect minor signals of change to guide their business to stay competitive.

Ugalde-Binda et al. (2014) concentrate their study on the influence of the intellectual capital of the entrepreneur on the results of the organizational innovation. The main characteristics of the entrepreneurs were identified: commitment to quality, work hard, ability to adapt to change, perseverance, business experience and motivation.

Felício at al. (2012) used factor analysis methods to identify structures associated with human and social capital in a small country with an open-economy, based on a survey of SMEs across different sectors. The purpose of the research was to investigate the influences of entrepreneurial and managerial behaviours on the relationship between human capital and social capital. The results indicated that the principal factor was highly correlated to the variables of experience, professional proficiency and cognitive ability, which were predominant characteristics of the entrepreneur, as well as some status variables such as interlinking, family support, personal relations and social relations.

The procedure developed to the quantitatively assess the entrepreneurial capacity is presented in subsection Quantitative assessment of the entrepreneurial capacity.

\section{Innovation and general categories of innovation}

The concept of innovation is diversified, depending mainly on its application. To Drucker $(1985,17)$ innovation 'is the specific tool of entrepreneurs, the process by which they explore change as an opportunity for a different business or a different service'.

Luecke and Katz (2003) consider innovation as the embodiment, combination or synthesis of knowledge into new products, processes or services that provide value in an original or relevant way.

Accordingly to Gundling (2000) innovation can be seen as new ideas associated with actions that produce results coated with originality, of amplitude in relation to the beneficiary audience, and of relevance, measured by their ability to solve more complex issues.

An innovative company, according to the Oslo Manual (OECD, 2005), is one that has introduced an innovation during a certain period of analysis. It points out that an innovative company is not necessarily the one that can always introduce a product or service successfully in the market, because these attempts may often fail. It defines innovative company as one that develops its own innovations, or in cooperation with other companies or public research organizations, or still a company that innovates by adopting innovations developed by other companies. The Oslo Manual was prepared by OECD (2005) together 
with the European Commission and involved experts from around thirty countries, aiming to provide a set of actions that can produce significant results regarding innovation.

Valladares at al. (2014) explored the gap that still persists on the determinants of innovation capacity, despite the numerous contributions by different authors, synthesizing it into a multidimensional structure composed of seven determinants of innovation capacity that result in performance on product and process innovation.

Crossan and Apaydin (2010), presented a compilation, based on a systematic review of the literature since the early 1980s, of different research perspectives involving a comprehensive view of organizational innovation, linking leadership, innovation as a process, and innovation as results. In this work, they considered four general categories of innovation: product, process, organizational, and marketing. Accordingly, to the Oslo Manual (OCDE 2005): Technological innovations in products or processes comprise new products or new processes, or significant technological improvements in products or processes. Organizational innovations concern the implementation of a new organizational method in the business practices of the companies, in the organization of their workplace or in their external relations. The main types of organizational and managerial innovation are the following: implementation of advanced management techniques; modified organizational structures; and implementation of new or modified corporate strategies. Marketing innovation refers to how the company relates to the market in order to expand its sales and customers network, exploring opportunities to offer better services to satisfy their requirements, needs, preferences and expectations.

This article required the development of a methodology to evaluate quantitatively the degree of innovation of the companies in each of its four general categories. This procedure used the theoretical framework provided by Bachmann and Destefani (2008) and it is presented in subsection Quantitative assessment of the company's degree of innovation.

\section{Methodology procedures}

The main point of this article is to present a quantitative study to analyse to what extent the degree of the four general categories of innovation affect the growth of various types of business in small companies and to what extent entrepreneurial capacity drives these types of innovation.

The study was developed with the objective of answering the following research questions:

1) Does the type of business affect the revenue growth rate of the companies?

2) Does the management of each type of business require different degrees of innovation in each of the four broad categories of innovation?

3) Which general categories of innovation are important to the revenue growth of the company for each type of business?

4) Does the entrepreneurial capacity of companies in each type of business influence the degree of innovation in any of the four general categories of innovation?

To answer these questions, we developed a procedure for the quantitative evaluation of the entrepreneurial capacity and the degree of innovation of the companies, which follows.

\section{The sample}

The study was accomplished based on a sample of small companies, composed of 48 companies of different types of business (companies with high-tech products or processes - TEC, specialized service companies - SS, companies selling products with their own brand - OB, and businesses using conventional processes - CP). 
The sample covered a wide range of companies (manufacturing, transportation and storage, food, automation, information and communication, education, health and social services) and high-tech companies (TEC) concentrated in robotics, automation and manufacturing of surgical products. The specialized service companies (SS) focused on IT activities and on managerial training courses. Companies with own brands (OB) and conventional processes $(\mathrm{CP})$ covered a broad range of economic activities, companies that do not have any special skills and labour-intensive use. The companies were randomly selected among those ones that replied to the survey.

\section{Quantitative assessment of the entrepreneurial capacity}

We considered the entrepreneurial capacity of the companies (EC) like that present in its top executives, usually the entrepreneur himself, which is a reasonable assumption for small companies. For its quantitative assessment, we proposed a procedure based on the characteristics of the entrepreneur identified by Oliveira and Fontenele (2009). Based on those characteristics, 41 sentences were developed, that portrayed attitudes or behaviour of the entrepreneur in practical situations of his business life. For each of these sentences, the respondent of the company - the top executives - have indicated the frequency of that practice among the options: always, often, sometimes, rarely, or never. For each of the five options for the behaviour of the entrepreneur, the weights 5, 4, 2.5, 1 and 0 have been assigned. The capacity of the leader entrepreneurial was then determined by the arithmetic mean of the weights of the 41 sentences.

The 41 sentences created were based on the significance of the word that expressed each one of the characteristics. For example, the four sentences that showed behavioural attitudes related to the attribute persuasion were: a) Listens to the needs or concerns of your employees, identifying those you need to consider, b) Observes the opinions of your employees with the vision of how to turn them into benefits for the company, c) For the conversations in which you are going to make persuasive proposals you prepare in advance, seeking to gather solid arguments, d) Acts with parsimony and firmness at the right time and never in an untimely manner in situations of conflict.

The proposed procedure aimed to evaluate the entrepreneurial capacity starting from the self-analysis of the executive of the company about his personal behaviour in dealing with daily problems of management and with arising opportunities.

\section{Quantitative assessment of the degree of innovation of the company}

The procedure for quantitative assessment of the degree of innovation of the companies, in turn, was based on the proposal by Bachmann and Destefani (2008), who developed a questionnaire used by the Servico de Apoio as Micro e Pequenas Empresas [Micro and Small Enterprises Support Service] (SEBRAE, 2009) of the Brazilian federal government, to research the innovation profile of SMEs in the Brazilian state of Parana. The procedure has evaluated innovation under 13 dimensions: offer, platform, brand, customer, relationship, solutions, value added, processes, organization, supply chain, presence, network and innovative environment. For each of these 13 dimensions, Bachmann and Destefani (2008) proposed 27 questions with answer options 'yes or no', to identify their presence or absence in the company.

To assess the degree of innovation of the company according to the proposed methodology, we developed our own questionnaire, which has two important changes compared to Bachmann and Destefani (2008): a) the number of questions was expanded to 41 questions, b) the questions were changed to allow up to five response options, unlike the binary option used by SEBRAE (2009). These changes seek to improve the discretionary power of companies regarding the assessment of their innovation capacity. The application of the questionnaire to the SMEs of Paraná by SEBRAE (2009) showed little differentiation for the majority of companies: in a scale where innovation degree varied 
discreetly between 1 and 4, the majority, 96\% of the 530 companies surveyed stood between grades 1 and 2 (the higher the innovation degree, more innovative is the company).

To increase the number of questions we used the list of the 269 'weapons of competition' (capabilities and internal resources of the company) provided by Contador (2008, Appendix). We have included only 'weapons of competition' characteristics that proved to be relevant to each of the four general categories of innovation. For example, for marketing innovation, one of the questions based on the list of weapons of competition was: Does the company make sales through new forms of customer access, such as direct sales or online sales?

This procedure generated a questionnaire with 54 questions, of which 10 were about product innovation, 13 about marketing, 14 about process and 17 about organizational innovation. The questions also dealt with the main concepts of innovation (Bacon and Butler, 1998, Bell and Pavitt, 1995, Drucker, 1985, Hesselbein, at al., 2001, Hamel, 2000, Hamel and Prahalad, 1995). One of the questions for assessing the degree of product innovation was the following: 'Does the company follow the technological evolution of competing products?'

The response options offered in the questionnaire were the following: never, rarely, sometimes, often, always, and the abandonment option (not applicable). For each answer choice, integers were associated ranging from 1 to 5 (or 0 , when not applicable). The indicator that reflects the degree of innovation of the company was then given by the arithmetic mean of the response values to the 54 questions.

To test the effectiveness of the questionnaire for distinguishing different degrees of innovation within and between companies we submitted a pilot test with four companies, each with recognized innovative capacity in one or more types.

To check differences between companies in the same type of innovation, we applied the non-parametric test of signals, as all companies are subject to the same set of questions for each type of innovation. To identify differences between innovation types in a single company, we used the analysis of variance, since the number of questions varies for each type. As the answers to questions (variable $\mathrm{X}$ ) were discrete values between 0 and 5, we applied the logarithmic transformation $\mathrm{Y}=1 \mathrm{n}(1+\mathrm{X})$, resulting for $\mathrm{Y}$ an approximately normal distribution of probabilities, which is necessary in the analysis of variance. The results of the pilot test with four companies showed that the questionnaire was effective in highlighting the differences intracompany (within the companies) and intercompany (between two companies).

The degree of reliability of the answers obtained by the questionnaire, for each type of innovation, was evaluated by the mean of the Cronbach alpha coefficient (Table 2).

Table 2. Cronbach alpha values - pilot test with four companies.

\begin{tabular}{|c|c|c|c|c|c|c|c|c|c|}
\hline \multirow{3}{*}{ Cronbach alpha values $(\alpha)$} & \multicolumn{9}{|c|}{ Types of business } \\
\hline & \multicolumn{3}{|c|}{$\mathrm{CP}$} & \multicolumn{2}{|c|}{$\mathrm{OB}$} & \multicolumn{2}{|c|}{ SS } & \multicolumn{2}{|c|}{ TEC } \\
\hline & $k$ & $n$ & $\alpha$ & $n$ & $\alpha$ & $n$ & $\alpha$ & $n$ & $\alpha$ \\
\hline Entrepreneurial capacity & 41 & 12 & 0,94 & 12 & 0,92 & 12 & 0,93 & 12 & 0,96 \\
\hline Product Innovation capacity & 10 & 12 & 0,89 & 12 & 0,62 & 12 & 0,77 & 12 & 0,82 \\
\hline Marketing Innovation capacity & 13 & 12 & 0,90 & 12 & 0,81 & 12 & 0,88 & 12 & 0,87 \\
\hline Process Innovation capacity & 14 & 12 & 0,87 & 12 & 0,91 & 12 & 0,90 & 12 & 0,65 \\
\hline Organizational Innovation capacity & 17 & 12 & 0,89 & 12 & 0,88 & 12 & 0,81 & 12 & 0,88 \\
\hline
\end{tabular}

Legend: $k=$ number of items in the questionnaire, $n=$ number of respondents, $\mathrm{CP}=$ Conventional Processes, $\mathrm{OB}=$ Own Brand products, $\mathrm{SS}=$ Specialized Service companies, TEC $=$ High-Tech products or processes

Source: The authors.

\section{Statistical tests for analysing the research questions}

The application of the suggested statistical tests required that the variables: revenue growth rate of the company, entrepreneurial capacity and degree of innovation, in its four general categories of innovation, could be 
considered as coming from a population with a normal probability distribution, which was confirmed by the Kolmogorov-Smirnov test.

First, we determined the revenue growth rate $\left(G R_{j}\right)$ of each $j$ company of the sample. This was given by the quotient of revenue between the first year $\left(F_{j}^{1}\right)$ and the last year $\left(F_{j}^{n}\right)$ of a period of $n$ years, $n \geq 3$, by applying the equation $G R_{j}=\left(F_{j}^{n} / F_{j}^{1}\right)$. We adopted $\mathrm{n}=3$, that is, $F_{j}^{n}=F_{j}^{3}$. Data collection for the calculation of the revenue growth rate was made through a questionnaire sent to the companies, with the request to adopt $F_{j}^{1}=100$, due to secrecy issues.

Regarding the innovation degree, the following four innovation indicators $I D^{\ell}$, for $\ell=1,2,3$, and 4 , were built, where: $I D^{1}$ is the degree of product innovation, $I D^{2}$ is the degree of process innovation, $I D^{3}$ is the degree of marketing innovation, and $I D^{4}$ is the degree of organizational innovation. The values of $I D^{\ell}$ resulted from the average of the grades given to the questions used for this purpose.

For the analysis of the first research question (Does the type of business affect the revenue growth rate of the companies?) the values of $G R_{j}, j=1,2, \ldots, J_{k}$ and $k=1,2,3$ and 4 , where $J_{k}$ represents the number of companies in the sample that belonged to the $k$ type of business, were calculated, and the means $\mu_{k}=\left(\sum_{j} G R_{j, k}\right) / J_{k}, k=1,2,3$ and 4 , were compared through the fixed model of analysis of variance, in order to verify if all means could be considered statistically equal (hypothesis $H_{0}: \mu_{1}=\mu_{2}=\mu_{3}=\mu_{4}$ ). When rejection of hypothesis $H_{0}$ occurs, we applied the Tukey and Scheffé method to find out which of them were different from each other.

To analyze the second research question (Does the management of each type of business require different degrees of innovation in each of the four broad categories of innovation?), we adopted the same procedure as in the first question, comparing the means of the variables $I D^{\ell}, \ell=1,2,3$ and 4 , which occur within each type of business.

For each $\ell$ type of innovation, the tested means were $\mu_{k}^{\ell}=\left(\sum_{j} I D_{j, k}^{\ell}\right) / J_{k}$, where $J_{k}$ is the number of companies belonging to the $k$ type of business, $k=1,2,3$ and 4 , and $I D_{j, k}^{\ell}$ is the degree of innovation type $\ell$, of company $j$, belonging to the $k$ type of business.

To examine the third research question (Which general categories of innovation are important to the revenue growth of the company for each type of business?), we built a $4 x 4$ matrix, where the lines $\ell=1$, $2,3,4$ represent the general categories of innovation and the columns $k=1,2,3,4$, the types of business.

Each cell $(\ell, k)$ of this matrix contained the Pearson correlation coefficient $\left(\rho_{k}^{\ell}\right)$ between the revenue growth rate and the degree of innovation type $\ell$ of the $J_{k}$ companies of the sample that belonged to the type $k$ of business, hence $\rho_{k}^{\ell}=\left(G R_{j, k} ; I D_{j, k}^{\ell}\right), j \in($ type $k)$.

To analyze the fourth research question (Does the entrepreneurial capacity of companies in each type of business influence the degree of innovation in any of the four general categories of innovation?), it was calculated the Pearson correlation coefficient $\left(\theta_{k}^{\ell}\right)$ between the entrepreneurial capacity of companies of the $k$ type of business and the degree of innovation in each of its general categories, that is, the values of $\theta_{k}^{\ell}=\left(E C_{j, k} ; I D_{j, k}^{\ell}\right)$, where $E C_{j, k}$ and $I D_{j, k}^{\ell}$ represent, respectively, the entrepreneurial capacity and the degree of general categories of innovation $\ell$ of company $j$ belonging to the $k$ type of business. The analysis was conducted similarly to the third research question. 


\section{Presentation and analysis of results}

The values for the entrepreneurial capacity and innovation degree variables, for each type of companies in the sample, were obtained according to the procedures discussed in section Methodology procedures. To calculate the revenue growth rate of a $j$ company in the sample, we considered a three years period. By applying the Kolmogorov and Smirnov test, we found that the variables revenue growth of the company rate, entrepreneurial capacity and degree of innovation for the four general categories of innovation could be considered as part of a population with normal probability distribution. Thus, we adopted the Pearson coefficient for all correlation tests.

\section{Results presentation}

Table 3 exhibits the results of the analysis of variance that allowed checking, for each type of business, if there is a significant difference between the variables revenue growth rate and innovation degree in its four general categories of innovation. When, for each group of tested means, was obtained a tail value of the $F$ distribution smaller than $5 \%$, we tested which of the means could be considered superior to the others, which were highlighted in bold.

Table 3. Results of the analysis of variance for the mean test.

\begin{tabular}{|c|c|c|c|c|c|c|c|c|c|c|c|}
\hline \multicolumn{4}{|c|}{ Growth rate } & \multicolumn{4}{|c|}{$\begin{array}{l}\text { Degree of Product } \\
\text { Innovation }\end{array}$} & \multicolumn{4}{|c|}{$\begin{array}{l}\text { Degree of Process } \\
\text { Innovation }\end{array}$} \\
\hline $\mathrm{CP}$ & $\mathrm{OB}$ & SS & TEC & $\mathrm{CP}$ & $\mathrm{OB}$ & SS & TEC & $\mathrm{CP}$ & $\mathrm{OB}$ & SS & TEC \\
\hline \multicolumn{4}{|c|}{ Mean Values } & \multicolumn{4}{|c|}{ Mean Values } & \multicolumn{4}{|c|}{ Mean Values } \\
\hline 1.20 & 1.39 & 1.19 & 1.21 & 0.29 & 0.56 & 0.36 & 0.55 & 0.47 & 0.69 & 0.34 & 0.62 \\
\hline Fcal & Fcrit & Tail & $\Delta_{5 \%}$ & Fcal & Fcrit & Tail & $\Delta_{5 \%}$ & Fcal & Fcrit & Tail & $\Delta_{5 \%}$ \\
\hline 2.962 & 2.816 & 0.042 & 0.246 & 5.186 & 2.816 & 0.003 & 0.242 & 6.990 & 2.816 & 0.001 & 0.230 \\
\hline
\end{tabular}

\begin{tabular}{|c|c|c|c|}
\hline \multicolumn{4}{|c|}{$\begin{array}{c}\text { Degree of Marketing } \\
\text { Innovation }\end{array}$} \\
\hline $\mathrm{CP}$ & $\mathrm{OB}$ & SS & TEC \\
\hline \multicolumn{4}{|c|}{ Mean Values } \\
\hline 0.59 & 0.61 & 0.56 & 0.59 \\
\hline Fcal & Fcrit & Tail & $\overline{\Delta_{5}}$ \\
\hline 0.087 & 2.816 & 0.966 & 0.250 \\
\hline
\end{tabular}

\begin{tabular}{cccc}
\multicolumn{4}{c}{ Degree of Organizational } \\
Innovation \\
CP & OB & SS & TEC \\
\hline \multicolumn{4}{c}{ Mean Values } \\
0.46 & $\mathbf{0 . 6 0}$ & 0.46 & 0.41 \\
\hline Fcal & Fcrit & Tail & $\Delta_{5 \%}$ \\
3.563 & 3.285 & $\mathbf{0 . 0 3 9}$ & 0.275 \\
\hline
\end{tabular}

Note. CP, OB, SS, TEC: Types of Business, Fcal and Fcrit: test statistics (F by Snedecor) calculated and critical for $\alpha=5 \%$, respectively, Tail: P[Fcal $>$ Fcrit $]), \Delta_{5 \%}$ : minimum difference between means to reject the hypothesis of equality of means (Tukey and Scheffé method).

Source: The authors.

The value of $\Delta_{5 \%}$ represents the minimum nominal difference between the means for the hypothesis of equality to be rejected at the 5\% level of significance (Tukey and Scheffé method). This method is quite rigorous and even when the analysis of variance reveals a difference between the means, the nominal differences between them may fall below the value of $\Delta_{5 \%}$, but it is useful to indicate that one or those averages that are different from the others (highlighted in bold in the Table 3).

Table 4 shows, for each type of business, the correlation coefficients (when there was correlation) of the observed revenue growth rate in the considered period with the innovation degree for each of the four general categories of innovation $\left(\rho_{k}^{\ell}\right)$ (left block) and the correlation coefficients between entrepreneurial capacity and the innovation degree for each type of innovation $\left(\theta_{k}^{\ell}\right)$ (right block). 
Table 4. Values of the correlation coefficients between the variables and the tail of the t-test to verify the existence of correlation.

\begin{tabular}{|c|c|c|c|c|c|c|c|c|}
\hline \multirow[t]{3}{*}{$\begin{array}{c}\text { General categories of } \\
\text { innovation }\end{array}$} & \multicolumn{4}{|c|}{$\begin{array}{c}\text { Correlation coefficients between } \\
\text { growth rate and degree of } \\
\text { innovation }\left(\rho_{k}^{\ell}\right)\end{array}$} & \multicolumn{4}{|c|}{$\begin{array}{l}\text { Correlation coefficients between } \\
\text { entrepreneurial capacity and degree } \\
\text { of innovation }\left(\theta_{k}^{\ell}\right)\end{array}$} \\
\hline & \multicolumn{4}{|c|}{ Types of Business } & \multicolumn{4}{|c|}{ Types of Business } \\
\hline & $\mathrm{CP}$ & $\mathrm{OB}$ & SS & TEC & $\mathrm{CP}$ & $\mathrm{OB}$ & SS & TEC \\
\hline Product & $\begin{array}{c}0.74 \\
(.003)\end{array}$ & $\begin{array}{l}0,57 \\
(.026)\end{array}$ & $\begin{array}{c}0.67 \\
(.009)\end{array}$ & - & $\begin{array}{l}0.70 \\
(.006)\end{array}$ & $\begin{array}{l}0.89 \\
\left(0^{+}\right)\end{array}$ & - & $\begin{array}{c}0.58 \\
(.024)\end{array}$ \\
\hline Marketing & - & - & - & - & - & & - & - \\
\hline Process & $\begin{array}{c}0.70 \\
(.006)\end{array}$ & - & - & - & $\begin{array}{c}0.61 \\
(.018)\end{array}$ & $\begin{array}{c}0.61 \\
(.018)\end{array}$ & - & - \\
\hline Organizational & $\begin{array}{c}0.61 \\
(.018) \\
\end{array}$ & - & - & $\begin{array}{c}0.62 \\
(.016)\end{array}$ & $\begin{array}{c}0.63 \\
(.014)\end{array}$ & $\begin{array}{c}0.72 \\
(.004)\end{array}$ & - & - \\
\hline
\end{tabular}

\footnotetext{
Notes:

a) CP, OB, SS, TEC: Types of business. Numbers in the table represent Pearson's coefficient of correlation between the variables.

b) Within the brackets it is shown the tail of the t-test to verify the existence of correlation Source: The authors
}

\section{Discussion}

The answers to the first two research questions (1. Does the type of business of small companies affect their revenue growth rate? and, 2. Does the management of each type of business require different degrees of innovation in each of the four broad categories of innovation?) were found by analysing the values shown in Table 3 . This analysis allows stating that:

- Companies with own brand products (OB type) have a higher revenue growth rate than others, and

- Companies belonging to the TEC type (high-tech products or processes) and OB type (own brand) showed a higher degree of innovation than the others, the former in product and process, and the latter in product, process and organizational innovation. It should be remembered that product and process innovation move in parallel.

Therefore, as results indicated, regarding revenue growth rate, the best option is to develop own brand products, but this is the type of business that requires a higher degree of innovation to sustain it (to stay in the market), followed by high-tech companies.

The answer to the third research question (Which general categories of innovation are important to the revenue growth of the company for each type of business?) was found by analysing data in Table 4 (left block), and we found that:

- For companies of the CP type (conventional process) three types of innovation affect revenue growth (significant correlation), and

- Companies of SS (specialized services), OB (own brand) and TEC companies has correlation with one type of innovation, the first two with product innovation, what make sense.

Hence, it was observed that innovation influences the company's revenue growth and this influence is stronger for companies with conventional processes (CP)

A question that aroused is: Why does the companies of the CP type are the most dependent on innovation to grow? One possible explanation is that perhaps the main differential for these companies resides in the own innovation, since they have low degree of innovation, unlike the other companies that presented greater degree of innovation, which means that the growth rate is less sensitive to the degree of innovation. The types of business of these other companies represented in themselves a competitive differential that leverage their growth. 
It is worth comparing these results with those obtained by Varis and Littunen (2010) who in a similar study found that company growth is not affected by innovation category. If all 48 companies ware brought together in a single sample (without separation by business type), our study would have reached the same conclusion as Varis and Littunen (2010): correlation coefficients between growth and innovation degree of $0.33,0.08,0.26$ and 0.12 for product, marketing, process and organizational innovation, respectively. Therefore, we could better understand the effect of innovation on revenue growth by studying this issue with different type of business, as does the methodology here presented.

From this analysis, we can state that:

- For CP companies, innovation is a timely instrument to leverage revenue growth because they have a low level of innovation, and that

- $\mathrm{OB}$ and TEC companies need to maintain a high degree of innovation to sustain their business, although this will improve their revenue growth moderately.

The statement contained in the second sentence above is based on the fact that all OB and TEC companies have a high degree of innovation and have been in the market for a long time, meaning that innovation is not a distinguishing factor, but rather a qualifying one (needed) to generate sustainable rates of revenue growth.

To answer the fourth research question (Does the entrepreneurial capacity of companies in each type of business influence the degree of innovation in any of the four general categories of innovation?) we analysed the data on the right block in Table 4. We see that, for CP and OB types of business, entrepreneurial capacity is an important attribute to leverage their innovation degrees (significant correlation was found with three general categories of innovation $(0.70,0.61,0.63$ for CP companies, and 0.89, $0.61,0.72$ for OB companies), which did not occur for SS and TEC types of business.

From this analysis, we observe that:

(1) Since OB companies have higher degrees of innovation (according Table 3), their entrepreneurial capacity is an important factor to support their business, as long as through this ability they can maintain or improve their innovation degree;

(2) OB companies has the highest correlation between entrepreneurial capacity and product innovation (0.89), showing that this ability is critical to their core business, as they develop products with own brand,

(3) Regarding CP companies, entrepreneurial capacity can leverage their innovation degree, especially for those general categories of innovation that favour revenue growth rate. Therefore, this capability is an important expertise for them to grow through innovation. In this case, we observed a positive interaction of the spiral 'entrepreneurship, innovation and growth'.

The results of the study confirmed the article by Takahashi and Takahashi (2007) about the three stages of the life cycle of the companies - fluid, transient and specific. These authors claim that, during these phases, product and process innovation rates change, as well as the features of the organizations and their management, and by moving from one phase to the next, companies develop different types of innovation.

\section{Considerations about the sample size}

One aspect that can generate controversy concerns the sample size used in the study conducted here, that is, if it is large enough to ensure confidence in the results obtained.

The test to check the existence of correlation $\left(\mathrm{H}_{1}: \varrho>0\right)$ is performed by means of the $t$ distribution, which simultaneously considers the value obtained for the estimation of $\varrho(r)$ and the number of sample elements $n$. And the tail of the distribution, $\operatorname{Pr}\left[t>t_{c a}\right]$, where $t_{c a l}$ is the value of the distribution $t$ calculated 
from the sample data, indicates the significance level $\alpha$ of the test. Thus, if $\alpha$ is sufficiently small (such as those shown in Table 4), it is concluded that there is correlation regardless of consideration of sample size.

The same applies to the analysis of variance, which tests the equality of the averages of several samples. This test is performed through the $F$ distribution, considering the $F_{c a l}$ value calculated from the variables values provided by the samples combined with the number of elements $n$ from the samples, where the significance level of the test is given by $\operatorname{Pr}\left[F>F_{c a}\right]$, indicated in Table 3 by "tail"

Therefore, the sample size considered in the present study does not invalidate or reduce confidence in the results obtained, which leads to the conclusion that the methodology proposed for the study was adequate, since it showed distinctions between companies of different types of business in general consistent with the expectations supported by the theory, summarized in the following section.

\section{Conclusions and Final Remarks}

The purpose of this article was to present a quantitative study in order to analyse to what extent the degree of the different types of innovation affects the revenue growth of various types of small business, and, in addition, to what extent entrepreneurial capacity drives these types of innovation. The approach relating the three variables mentioned above gives uniqueness to the study.

\section{Alignment between proposed methodology and theory}

One of the contributions of this article is the proposition of the procedures for the quantitative evaluation of the entrepreneurial capacity in small enterprises, as well as of their degree of innovation.

The evaluation of the entrepreneurial capacity of the company was based on the expertise of the main manager of the company, which is acceptable when it comes to small companies. It was then necessary to identify the main characteristics of the entrepreneur, which was done by analysing the literature as explained in subsection Attributes of the entrepreneur, highlighting the following studies.

McClelland (1961), that has identified ten personal skills often found in successful entrepreneurs. Carland at al. (1992) that has developed the Carland Entrepreneurship Index, which takes into account the four following functions: 1) personality traits, 2) risk propensity, 3) propensity for innovation, and 4) strategic posture. Schumpeter (1985) that saw the entrepreneur how a innovator agent responsible to combat the decline of the economic cycles, preventing the decline of the revenue. Bateman and Snell (1998) that observe the entrepreneurs how a determined and effective leader, creative and motivated person, obsessed with opportunities. Hisrich et al. (2010), that see three categories of the skills present in the entrepreneurs: technical, administrative and personal (ability to take risks, spirit of innovation and persistence). Drucker (1985) that see the following key roles of the entrepreneurs: innovation, risk-taking and a permanent state of breaking paradigms. Olivari (2016) that has identified the following main traits of personalities: need of achievement, internal locus of control and persistent self-efficacy

After the knowledge acquired in the literature about the characteristics of the entrepreneur, the questionnaire for evaluate the entrepreneurial capacity of the company was built in two steps: first, was identified in the literature an instrument that translated the entrepreneurial characteristics in sentences, having been found in Oliveria and Fontenele (2009) sentences for fifteen characteristics of then. After that, 41 statements were created that could express these fourteen characteristics, generating a Likert questionnaire.

The assessment of each company's degree of innovation, in its turn, was based on the Oslo Manual that specifies the concept and content of each of the four classic types of innovation, and in the framework provided by Bachmann and Destefani (2008) that evaluates the innovation under 13 dimensions (see subsection Quantitative assessment of the degree of innovation of the company) 
Considering these two constructs, a Likert questionnaire was created containing 54 questions to assess the degree of the four types of innovation (10 questions for product innovation, 13 for marketing innovation, 14 for process innovation and 17 for organizational innovation). These questions are an adaption of the list of the 264 "weapons of competition" (capabilities and internal resources of the company) provided by Contador (2008, Appendix). Was included only weapons of competition characteristics that proved to be relevant to each of the four types of innovation. Finally, it was verified whether these questions addressed the main concepts about innovation contained mainly in Bacon and Butler, 1998, Bell and Pavitt, 1995, Drucker, 1985, Hesselbein, at al., 2001, Hamel, 2000, Hamel and Prahalad, 1995.

\section{About the findings of the research}

Another contribution of this article resides on the several conclusions about the relationships among of the three variables considered in the study: degree of innovation, types of innovation and the revenue growth of the enterprise

Four types of business were proposed for separating the companies in our sample. Three of them, on one side, presented some distinctive attribute that can bring advantage from revenue growth, but on the other side, they may require a better performance in innovation and entrepreneurial capacity.

By studying a sample of 48 companies, it was possible to identify, in addition to the opportunities, the necessary conditions for the growth of companies in the market. The conclusions summarized below may be of interest to small business entrepreneurs.

In companies with conventional processes (CP), the innovation factor not only affect revenue growth but is also an appropriate instrument to achieve it. Their entrepreneurial capacity became an important instrument to improve their degree of innovation, and consequently their revenue growth. The spiral entrepreneurship, innovation and growth is clearly observed here.

Companies with own brand products $(\mathrm{OB})$ are those that provide the highest rate of revenue growth over a period of time, but this is the type of business that require the highest degree of innovation to stay in the market, although innovation do not affect their revenue growth rate (it is a qualifying factor). The entrepreneurial capacity is also an important tool to leverage their innovation degree, particularly product innovation, which constitutes their core business. Here we could also observe the entrepreneurship, innovation and growth spiral.

For specialized service companies (SS), which were represented in the sample by eight software development companies and four managerial training companies, the results contributed very little to unravel the relations between entrepreneurial capacity, innovation and revenue growth rate. These companies, curiously, do not present outstanding levels of innovation degree and revenue growth rate. Although they show a correlation between the rate of revenue growth and product innovation, they did not present a correlation between the degree of innovation and the entrepreneurial capacity, for any type of innovation. New studies are necessary for a better understanding of this type of companies, which seem to live in a world apart.

After OB companies, technology companies (TEC) are those that require a higher innovation degree to sustain them in the market. Innovation degree is not a factor that could be used to enhance their revenue growth rate, but it is an essential factor for keeping them in the market. They differ in relation to the degree of innovation in product and process, which seems logical, but do not present strong correlation between entrepreneurial capacity and these types of innovation. This seems to show that a "good idea" is enough for business success, even if the entrepreneur does not have high entrepreneurial capacity. 


\section{Comparison with other literature studies}

The literature presents few articles dealing with empirical studies involving the three variables considered here involving the SME. Most of them deal with the relationship between two of them, usually entrepreneurship and growth or entrepreneurship and innovation. When it involves all three variables, it usually deals with growth not of the company but of the regional economy. As an example of this last case, we can cite Galindo (2013) whose study aims to analyze the relationships between entrepreneurship, innovation and economic growth, and concludes that economic activity promotes entrepreneurship and innovation activities, and the latter enhances economic activity.

As examples of studies relating entrepreneurship and growth, we can cite Lee and Lee (2014) and Man $e t$ al (2008). The first involves study with start-up companies and concludes that, although the entrepreneur's human capital is known to affect his/her decision on exit strategies, the actual successful exit of a start-up is primarily due to hard-working characteristics of the entrepreneur. Man et al (2008) investigate the relationships between entrepreneurial characteristics and firm performance and conclude that there is evidence for the direct and indirect contributions of the entrepreneur's opportunity, relationship, innovative, human and strategic competencies in affecting the long-term performance of an SME via competitive scope and organizational capabilities.

As examples of studies relating innovation, and entrepreneurship we can cite Sahut and Peris-Ortiz (2014) and Varis and Littunen (2010). The first examines small businesses, innovation, and entrepreneurship, and show that, although these three concepts have their own specific literature and can be deal with independently, they are closely related. The authors conclude that small businesses provide the most conducive environment for entrepreneurship and innovation that are not necessarily sustained by the know-how and resources characteristic of large-scale production, but require commitment and close cooperation between company members.

Varis and Littunen (2010) examine the information sourcing practices of small to medium-sized enterprises associated with the development of different types of innovation (product/process/market/organizational). The relationship between different types of innovation and firms' performance is also examined. The findings also imply the need for entrepreneurs and their firms to upgrade their competences in order to enhance their innovation and networking capabilities. In a similar study presented here, these authors conclude that company growth is not affected by the innovation category, contrary to the result obtained here. However, they do not separate companies into business types. Therefore, seems that under this criterion, it is possible to obtain results that are more revealing.

Regarding the influence of entrepreneurial capacity on the innovation degree, and of this on the revenue growth of the companies, the results of the study with the sample of 48 companies were, in general, consistent with the study by Brito at al. (2009). Their study addressed the Brazilian chemical industry and concluded that there is a positive and statistically significant relationship between innovation indicators and net revenue growth. Our results were also consistent with Fernandes and Santos (2008), who concluded that entrepreneurial orientation affect the success of innovations.

To expand the results of this study, additional research on specialized service companies (SS) deserves particular interest, once presented a very different behaviour from the other types of companies. Are important companies that help to improve the capacity of management of other companies, developing management software and increasing the human resources capacities through training. These arguments justify the searching for a better understanding of the behaviour of this type of company. 


\section{References}

AHMED, U.; SHAH, S. A.; QURESHI, M. A.; SHAH, M. H.; KHUWAJA, F. M. Nurturing innovation performance through corporate entrepreneurship: The moderation of employee engagement. Studies in Business and Economics, v. 13, n. 2, p. 20-30, 2018.

ALEXY, O.; FREDERIKSEN, L.; HUTTER, K. Call for papers for a special issue on pushing the boundaries of open and user innovation. Innovation: Organization \& Management, v. 19, n. 3, p. 403-406, 2017

ARSHI, T.; BURNS, P. Entrepreneurial Architecture: A Framework to Promote Innovation in Large Firms. Journal of Entrepreneurship, v. 27, n. 2, p. 151-179, 2018.

BACHMANN, D. L.; DESTEFANI, J. H. Metodologia para estimar o grau de inovação nas MPE. Available at: http://www.bachmann.com.br/website/documents/ArtigoGraude InovacaonasMPE.pdf L. Accessed: 13 July 2018

BACON, F. R. Jr.; BUTLER, T. W. Jr. Achieving planned innovation: A proven system for creating successful new products and services. 3rd ed. New York: The Free Press, 1998.

BATEMAN, T. S.; SNELL, S. Administração: Construindo Vantagem Competitiva. São Paulo: Atlas, 1998.

BELL, M.; PAVITT, K. The development of technological capabilities. In: UL HAQUE, I.; BELL, M.; DAHLMAN. C.; LALL, S.; PAVITT, K. (eds). Trade, technology and international competitiveness 69-101. Washington, DC: The World Bank. 1995.

BIANCHI, C.; WINCH, G; COSENZ, F. Experimenting lean dynamic performance management systems design in SMEs. International Journal of Productivity and Performance Management, v. 67, n. 7, p. 1234-1251, 2018.

BRITO, E. P. Z.; MORGANTI, F.; BRITO, L. A. L. Inovação e o Desempenho Empresarial: Lucro ou Crescimento? RAE Eletrônica, v. 8, n. 1, p. 1-25, 2009. Available at: http://rae.fgv.br/sites/rae.fgv.br/files/artigos/10.1590 S1676-6482009000100007.pdf. Accessed: 15 July 2018

CARLAND, J. W.; CARLAND, J. A. C.; HOY, F. S. An entrepreneurship index: An empirical validation. Frontiers of Entrepreneurship Research, v. 25, n. 3, p. 244-265, 1992.

CHRISTENSEN, K.; NØRSKOV, S.; FREDERIKSEN, L.; SCHOLDERER, J. In search of new product ideas: Identifying ideas in online communities by machine learning and text mining. Creativity and Innovation Management, v. 26, n, 1, p. 17-30, 2017.

CONTADOR, J. C. Campos e armas da competição: novo modelo de estratégia. São Paulo: Saint Paul, 2008.

CROSSAN, M. M.; APAYDIN, M. Multidimensional framework of organizational innovation: A systematic review of the literature. Journal of Management Studies, v. 47, n. 6, p. 1154-1191, 2010.

DAVILA, T., EPSTEIN, M., SHELTON, R. As regras da inovação. Porto Alegre: Bookman, 2007.

DODGSON, M.; PERKMANN, M.; PHILLIPS, N. Introduction to the retrospective section: innovation in China, grassroots innovation, and city regions. Innovation: Management, Policy and Practice, v. 18, n. 4, p. 411-412, 2016. 
DRUCKER, P. F. Innovation and Entrepreneurship: Practice and principals. New York, NY: Harper, 1985.

DUOBIENE, J. Corporate entrepreneurship in Lithuanian mature organizations: Is it really working? Engineering Economics, v. 28, n. 1, p. 56-67, 2017.

FELÍCIO, J. A.; COUTO, E.; CAIADO, J. Human capital and social capital in entrepreneurs and managers of small and medium enterprises. Journal of Business Economics and Management, v. 13, n. 3, p. 395-420, 2012.

FERNANDES, D. Von Der H.; SANTOS, C. P. Entrepreneurial orientation: a study into the consequences of entrepreneurship in organizations. RAE Eletrônica, v. 7, n. 1, p. 1-22, 2008. Available at: $\quad$ http://www.scielo.br/scielo.php?script=sci_arttext\&pid=S1676-56482008000100007 / doi.org/10.1590/S1676-56482008000100007. Accessed: 10 August 2018.

FEUERSCHÜTTE, S. G.; ALPERSTEDT, G. D.; GODOI, C. K. Entrepreneurship and competence: an essay about complementarity and convergence of the constructs. GESTÃO.Org - Revista Eletrônica de Gestão Organizacional, v. 10, n. 3, p. 509-536, 2012.

FONTENELE, R. E. S. Entrepreneurship, competitiveness and economic growth: Empirical evidence. Revista de Administração Contemporânea, v.14, n. 6, p. 1112-1094, 2010.

GALINDO, M. A.; MENDEZ, M. T. Innovation, entrepreneurship and economic growth. Management Decision, v. 51, n. 3, p. 501-514, 2013.

Entrepreneurship, economic growth, and innovation: are feedback effects at work?

Journal of Business Research, v. 67, n. 5, p. 825-829, 2014.

GARCIA-HERRERA, C.; PERKMANN, M.; CHILDS, P.R.N. Industry-led corporate start-up accelerator design: Lessons learned in a maritime port complex. Proceedings of International Design Conference, DESIGN 2018, 4, 1845-1856, Pasay City, Philippines. doi:10.21278/idc.2018.0548, 2018

GUNDLING, E. The 3M way to innovation. Tokio: Kondasha International, 2000. Available at: https://jasonpuckettsign.files.wordpress.com/2017/05/the-3m-way-to-innovation-balancing-peopleand-profit-by-ernest-gundling.pdf, Accessed: 17 August 2018

HAMEL, G. Leading the revolution. Rio de Janeiro: Campus, 2000.

HAMEL, G.; PRAHALAD, C. K. Competing for the future. Rio de Janeiro: Campus, 1995.

HESSELBEIN, F; GOLDSMITH, M.; SOMERVILLE, I. Leading for innovation - Foreword. New York: Jossey-Bass, 2001.

HISRICH, R. D.; PETERS, M. P.; SHEPHERD, D.A. Entrepreneurship, 10th ed. New York, NY: McGraw Hill, 2010.

KORUNKA, C.; KESSLER, A.; FRANK, H.; LUEGER. M. Personal characteristics, resources, and environment as predictors of business survival. Journal of Occupational and Organizational Psychology, v. 83, n. 4, p. 1025-1051, 2010.

LADO-SESTAYO, R.; NEIRA-GÓMEZ, I.; CHASCO-YRIGOYEN, C. Entrepreneurship at Regional Level: Temporary and Neighborhood Effects. Entrepreneurship Research Journal, v. 7, n. 4, p. 1-12, 2017. Doi: 20170111. 
LEE, S. M.; LEE, B. Entrepreneur characteristics and the success of venture exit: an analysis of singlefounder start-ups in the U.S. International Entrepreneurship and Management Journal, 11(4), pp. 891-905, 2014.

LUECKE, R.; KATZ, R. Managing creativity and innovation. Boston: Harvard Business School Press, 2003.

MAN, T. W. Y.; LAU, T.; SNAPE, E. Entrepreneurial competencies and the performance of small and medium enterprises: An investigation through a framework of competitiveness. Journal of Small Business and Entrepreneurship, v. 21, n. 3, p, 257-277, 2008.

McCLELLAND, D. C. The Achieving Society, Princeton, NJ: D. Van Nostrand, 1961.

NEWBERT, S. L.; GOPALAKRISHNAN, S.; KIRCHHOFF, B. A. Looking beyond resources: Exploring the importance of entrepreneurship to firm-level competitive advantage in technologically intensive industries. Technovation. v. 28, n. 1, p. 6-19, 2008. Doi:10.1016/j.technovation.2007.07.002

NIAZI, A. The role of entrepreneurship, innovation and marketing capability in small and medium-sized enterprises (Smes). International Journal of Economic Perspectives, v. 11, n. 3, p. 1748-1759, 2017.

OLIVARI, J. Entrepreneurial traits and firm innovation. Eurasian Business Review, v. 6, n. 3, p. 339360, 2016. doi: 10.1007/s40821-016-0060-6

ORGANIZATION FOR ECONOMIC CO-OPERATION AND DEVELOPMENT [OECD]. Oslo Manual, 2005. The measurement of scientific and technological activities - Proposed guidelines for collecting and interpreting technological innovation data. Available at: http://www.oecd.org/science/inno/2367580.pdf, Accessed: 12 January 2018

PENG, M. W.; SUN, W.; VLAS, C. MINICHILLI, A.; CORBETTA, G. An Institution-Based View of Large Family Firms: A Recap and Overview. Entrepreneurship Theory and Practice, v. 42, n. 2, p. 187-205, 2018. Doi: 0.1177/1042258717749234.

PRIYANTO, S. H.; SANDJOJO, I. Relationship between entrepreneurial learning, entrepreneurial competencies and venture success: Empirical study on SMEs. International Journal of Entrepreneurship and Innovation Management, v. 5, n. 5/6, p. 454-467, 2005.

QIAN, H. Knowledge base differentiation in urban systems of innovation and entrepreneurship. Urban Studies, v. 54, n. 7, p. 1655-1672, 2017.

SAHUT, J. M; PERIS-ORTIZ, M. Small business, innovation, and entrepreneurship. Small Business Economics, v. 42(4), p.663-668, 2014

SCHUMPETER, J. A. The theory of economic development: An inquiry into profits, capital, credit, interest, and the business cycle, 2nd ed. São Paulo: Nova Cultural, 1985.

SERVIÇO DE APOIO ÀS MICRO E PEQUENAS EMPRESAS [SEBRAE]. Perfil do grau de inovação das MPES do Paraná, 2009. Available at: http://docplayer.com.br/8777173-Perfil-do-graude-inovacao-das-mpes-do-parana.html /. Accessed:20 August 2018

SCHMITZ, A.; URBANO, D.; DANDOLINI, G. A.; SOUZA, J. A.; GUERRERO. M. Innovation and entrepreneurship in the academic setting: a systematic literature review. International Entrepreneurship and Management Journal, v. 13, n. 2, p. 369-395, 2017. Doi: 10.1007/s11365-0160401-z

STOTT, N.; TRACEY, P. Organizing and innovating in poor places. Innovation: Organization \& 
Management, v. 20, n. 1, p. 1-17, 2018.

TAKAHASHI, S.; TAKAHASHI, V. P. Gestão de inovação de produtos: estratégia, processo, organização e conhecimento. Rio de Janeiro: Elsevier, 2007.

TAO, G.; QIUYING, Y. The raise of innovative enterprise's entrepreneurship. In: $4^{\text {th }}$ International Conference on Wireless Communications, Networking and Mobile Computing, WiCOM 2008. doi: 10.1109/WiCom.2008.1430.

TOMY, S.; PARDEDE, E. Opportunity Evaluation Using Uncertainties in Software Entrepreneurship. Entrepreneurship Research Journal, v. 7, n. 3, p. 1-14, 2017. Doi: 10.1515/erj-2016-0044

UGALDE-BINDA, N.; BALBASTRE-BENAVENT, F.; CANET-GINER, M. T.; ESCRIBÁ-CARDA, $\mathrm{N}$. The role of intellectual capital and entrepreneurial characteristics as innovation drivers. Revista Innovar. v. 24, n. 53. P. 41-60, 2014.

VALLADARES, P. S. D. A.; VASCONCELLOS, M. A.; Di SERIO, L. C. Innovation capability: A systematic review of the literature. Revista de Administração Contemporânea, v. 18, n. 6, p. 598-626. 2014.

VARIS, M.; LITTUNEN, H. Types of innovation, sources of information and performance in entrepreneurial SMEs. European Journal of Innovation Management, v. 13, n. 2, p. 28-154, 2010.

WEBER, M. The protestant ethic and the spirit of capitalism. London: Routledge, 2005.

WRIGHT, M., TARTARI, V.; HUANG, K. G.; Di LORENZO, F.; BERCOVITZ, J. Knowledge Worker Mobility in Context: Pushing the Boundaries of Theory and Methods. Journal of Management Studies, v. 55, n. 1, p. 1-26. 2018. Doi: 10.1111/joms.12316

ZACHARY, R. K.; MISHRA, C. S. The Future of Entrepreneurship Research: Calling All Researchers. Entrepreneurship Research Journal, v. 1, n. 1, p. 1-13, 2011. Doi: 10.2202/2157-5665.1016

ZAMPIER, M. A.; TAKAHASHI, A. R. W. Entrepreneurial competencies and processes of entrepreneurial learning: A conceptual research model. Cadernos EBAPE/BR, v. 9 (special ed.), p. 564-585, 2011. 